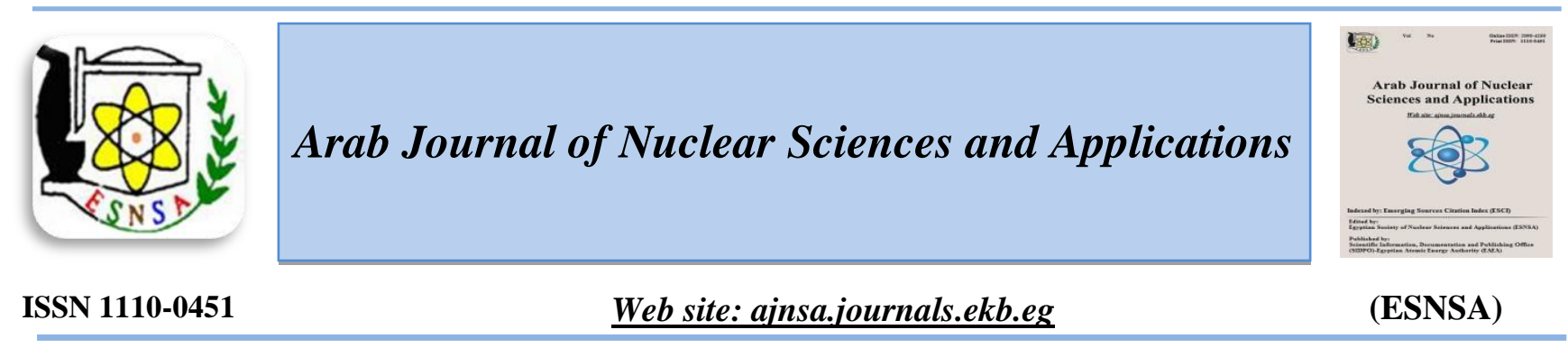

\title{
Effect of Poly Vinylidine Addition on the Structural and Electrical Properties of Nickel Zinc Ferrite
}

\author{
B. I. Salem*, O.M. Hemeda, A. Tawfik, M.M. El-Shahawy \\ Physics Department, Faculty of Science, Tanta University, Egypt
}

\begin{abstract}
Received $4^{\text {th }}$ Sept 2018 Samples of $\mathrm{Ni}_{0.3} \mathrm{Zn}_{0.7} \mathrm{Fe}_{2} \mathrm{O}_{4}$ and composite films of $x \%\left(\mathrm{Ni}_{0.3} \mathrm{Zn}_{0.7} \mathrm{Fe}_{2} \mathrm{O}_{4}\right) /(\mathrm{PVDF})(1-\mathrm{x}),(\mathrm{x} \%=5,10,15,20$ Accepted $8^{\mathrm{h}}$ May 2019 and $25 \%$ ) were synthesized using heavy duty ball milling. The sample milled for 90 hours shows that peak intensities of the initial oxides were reduced during the ball milling process and completely disappeared by annealing at $1373 \mathrm{~K}$. There are 2 peaks at $\left(2 \theta=18.6\right.$ and $\left.27^{\circ}\right)$ corresponding to planes (020) and (021) which are attributed to $\alpha$ - phase of (PVDF) where $\beta$-phase of PVDF is characterized by the peaks at $\left(2 \theta=20.8^{\circ}\right)$ corresponding to the (110) planes. The phase transformation from the nonpolar $\alpha$-phase to the polar electroactive $\beta$-phase of PVDF by increasing NZF content has been investigated by XRD analysis and FTIR spectroscopy. The DC resistivity of the composite samples at room temperature reaches a maximum at $5 \% \mathrm{NZF}$, and above this ratio, it begins to decrease. The dielectric constant and dielectric loss were studied at a constant frequency.
\end{abstract}

Keywords: NZF, Heavy duty ball milling, $\alpha$-phase to $\beta$-phase, XRD, FTIR spectroscopy,

$D C$ resistivity

\section{Introduction}

Ferrites are ferromagnetic oxides consisting of ferric oxide combined with metal oxide. On the basis of crystal structure, ferrites are grouped into three classes' namely hexagonal ferrite, garnet and spinel ferrite. The spinel ferrites are widely studied because of their numerous applications in several fields. Many novel methods are used to synthesize the ferrites, such as the microwave-assisted flash combustion technique [1], solid state method [2,3], sol-gel method [4], ball milling process [5] and citrate method [6]. PVDF's ferroelectric properties make this polymer of unique properties. PVDF is considered to have a stronger piezoelectric response compared with other polymers and is considered to be easy to process into films $[7,8,9]$. Other than its piezoelectric properties, poly (vinylidene fluoride) is a useful polymer due to its chemical stability, resistance to organic solvents, and high elastic modulus compared with other polymers. PVDF has proved to be very useful as a dielectric material because of its high permittivity and dielectric strength and low dissipation factor. Macroscopic stretching of the polymer sample can transform the $\alpha$-phase into the polar $\beta$ - or form I phase with molecules in the all-trans, (TT) conformation. The $\beta$-phase is most interesting because it is ferroelectric. Additional polymorphs that are of minor interest in this work, are the $\gamma$ and $\delta$-phases. Each PVDF chain has a coupling of positive and negative charges referred to as a dipole. The negatively charged fluorine atoms are coupled with the positively charged hydrogen atoms or protons. The dipoles are rigidly attached to the carbon backbone and their orientation depends on the polymer crystal structure. This orientation of the dipoles determines which crystalline structures of PVDF are piezoelectric. The $\beta$ - phase has a highly polar arrangement of the hydrogen and fluorine atoms. All-trans structures

Corresponding author: basant.salem@science.tanta.edu.eg

DOI: 10.21608/ajnsa.2019.5034.1116

(C) Scientific Information, Documentation and Publishing Office (SIDPO)-EAEA 
of the $\beta$ phase align the charged hydrogen and fluorine atoms and produce a net polarization of the unit cell. The dipoles along the carbon backbone, and within the crystal, align themselves maximizing spontaneous polarization within the unit cell $[7,10,11,12]$.

\section{Experimental Details}

The powder sample $\mathrm{Ni}_{0.3} \mathrm{Zn}_{0.7} \mathrm{Fe}_{2} \mathrm{O}_{4}$ was milled for 41, 67 and 90 hours and samples were annealed at 1073,1273 and 1373K. The sample milled for 90 hours and its nanocomposite with different percent of $\mathrm{x} \% \mathrm{Ni}_{0.3} \mathrm{Zn}_{0.7} \mathrm{Fe}_{2} \mathrm{O}_{4} /(\mathrm{PVDF})(1-\mathrm{x}), \quad(\mathrm{x}=5-25 \%)$ were synthesized by heavy duty ball milling. $\mathrm{X}$-ray studies were carried out by X-ray diffractometer at room temperature using a Philips model (PW1729) using radiation source $\mathrm{Cu}-\mathrm{K} \alpha$ radiation $(\lambda=1.5411 \AA)$. Infrared spectra (IR) of the investigated samples were recorded using the infrared spectrometer, (BRUKER FTIR spectrometer tensor 27) in the range 200-4000 $\mathrm{cm}^{-}$ ${ }^{1}$. Scanning Electron Microscope model JEOL JSM $5200 \mathrm{LV}$ has been used for morphological study of the sample surface. A TEM model (Transmission Electron Microscope JEOL - 100SX) was used to give information about the shape of particles and its distribution. An electrometer type 610 Keithly was used to measure the DC resistivity and RLC bridge type $815 \mathrm{~B}$ was used to measure dielectric constant and dielectric loss.

\section{Results and Discussion}

Figure (1 a) Shows the diffraction pattern of the pure spinel phase of $\mathrm{Ni}_{0.3} \mathrm{Zn}_{0.7} \mathrm{Fe}_{2} \mathrm{O}_{4}$ which was prepared by heavy duty ball milling technique for 90 hours and annealed at $1373 \mathrm{~K}$ for 4 hours. All peaks were matching the standard pattern of $\mathrm{NiZnFe}_{2} \mathrm{O}_{4}$ (JCDF) except for some peaks that belong to second phase $\mathrm{ZnO}$ at $\left(2 \theta=37\right.$ and $\left.39^{\circ}\right)$ $[13,14]$. The diffraction pattern of (PVDF) is shown in Figure $(1 \mathrm{~b})$. It can be seen that there are three strong diffraction peaks at $(2 \theta=18.6,20.3$ and $27^{\circ}$ ) which are attributed to the crystal planes of pure poly (vinylidene fluoride) (PVDF). These are characteristic peaks of $\alpha$ - form crystal of (PVDF).

Figure (2) shows the X-ray diffraction pattern (XRD) of the PVDF nanocomposite samples with different percent of $x \% \mathrm{Ni}_{0.3} \mathrm{Zn}_{0.7} \mathrm{Fe}_{2} \mathrm{O}_{4},(\mathrm{x}=5-25 \%)$ prepared by heavy duty ball milling technique for 90 hours and annealed at $1373 \mathrm{~K}$ for 4 hours. It is evident that the XRD peaks of the initial oxides were present and their intensities were reduced during the ball milling process.

It could be seen that there are three strong diffraction peaks at $\left(2 \theta=18.6\right.$ and $\left.27^{\circ}\right)$ which are attributed to $\alpha$-phase of pure poly (vinylidene fluoride) (PVDF) and at $\left(2 \theta=20.3^{\circ}\right)$ attributed to $\beta$ - phase of PVDF. The spectra of the nanocomposite shows that incorporation of ferrite nanoparticle has a considerable effect on the crystalline morphology structure of pure (PVDF) and it can also be noted that by increasing the ferrite percentage, the (PVDF) diffraction peaks intensity decreases and disappeared completely at $100 \% \mathrm{Ni}_{0.3} \mathrm{Zn}_{0.7} \mathrm{Fe}_{2} \mathrm{O}_{4}$. The XRD diffractograms of the composite show broad peaks as a result of the presence of nanoparticles [15].

The crystallite sizes of the samples were estimated by broadening analysis of XRD peaks using Scherer's equation [16].

$$
\mathrm{t}=\frac{\mathrm{k} \lambda}{\beta \cos \theta}
$$

Where $\mathrm{k}=0.89$ is constant, $\theta$ is the diffraction angle, $\beta$ is the full width at half maximum of the peak in radian, $\lambda$ is the wave length of the $\mathrm{X}$-ray for $\mathrm{Cu}-\mathrm{K} \alpha$ radiation $\left(\lambda=1.541178 \mathrm{~A}^{\circ}\right)$.

From XRD, the calculated average crystallite size was found between 18-20 nm. The dependence of particle on calcination temperature and milling time are shown in Figure (3) for the samples $\mathrm{Ni}_{0.3} \mathrm{Zn}_{0.7} \mathrm{Fe}_{2} \mathrm{O}_{4}$.

Figure (4) shows the SEM morphological evolution for NZF samples. It is shown that the grain size tends to decrease both with milling time whereas, they increase for higher calcination temperature. The sizes estimated from SEM morphological are between $(20-26) \mathrm{nm}$ which is different from crystallite size given by Scherer's equation. As shown from SEM the grain size for the sample $\mathrm{Ni}_{0.3} \mathrm{Zn}_{0.7} \mathrm{Fe}_{2} \mathrm{O}_{4}$ milled at $40 \mathrm{~h}$ is high and begin to decrease by increasing milling time to (18.33) and (17.57) then increase by increasing calcination temperature to about (26) $\mathrm{nm}$ at 1373 $\mathrm{K}$.

It can be observed that the average crystallite sizes of the ferrite phase are smaller than of those the value obtained by TEM Table (1). The magnetostatics interactions between nanoparticles promote agglomeration. The agglomerated nanoparticles possess size higher than the size of nanoparticles determined by other technique such as TEM. 
As nanoparticles of $\mathrm{Ni}_{0.3} \mathrm{Zn}_{0.7} \mathrm{Fe}_{2} \mathrm{O}_{4}$ increases, the crystallinity of PVDF decreases an evident from the decrease of (110) peak intensity. The polymer crystalline phase nucleates in the piezoelectric $\beta$ phase for NZF composite. This fact is achieved for the NZF composite for nanoparticle contents around $(\mathrm{x}=25 \%)$. A similar behavior was previously observed in the study of (PVDF) /ferrite composite [17]. Figure (5) shows the TEM micrograph of pure PVDF and NZF/PVDF nanocomposites. It was found that the composite was made up of particles having a particle size distribution between $45.8 \mathrm{~nm}$ and $57.5 \mathrm{~nm}$. Although XRD is a useful tool for determining particle size, it does not give information about size distribution. TEM micrograph of PVDF shows a spherical particle and high homogeneity distribution of nanoparticles.

Figure $(6 \mathrm{a}, \mathrm{b})$ shows the room temperature IR spectra of the prepared ferrite $\mathrm{Ni}_{0.3} \mathrm{Zn}_{0.7} \mathrm{Fe}_{2} \mathrm{O}_{4}$ after ball milling $41 \mathrm{~h}, 67 \mathrm{~h}$ and $90 \mathrm{~h}$ and after calcination at $1073 \mathrm{~K}, 1273 \mathrm{~K}$ and $1373 \mathrm{~K}$ and for NZF/PVDF composite films in the range of (4001500) $\mathrm{cm}^{-1}$ respectively. The characteristic absorption bands, $v_{1}$ and $v_{2}$ assigned for tetrahedral and octahedral sites appeared in all spectra. For NZF samples, as the milling time increase, these absorption bands become broader and more intense. After calcination at $1073 \mathrm{~K}, 1273 \mathrm{~K}$ and $1373 \mathrm{~K}$ many absorption bands owing to the metal oxide-oxygen bond, disappeared and $v_{1}$ and $v_{2}$ still present. This indicates the formation of the ferrite phase and elimination of the oxide phases. For NZF/PVDF samples the FTIR spectra have absorption at 766, 1075, 1186, 1403 and $1432 \mathrm{~cm}^{-1}$ indicating the presence of $\alpha$-phase PVDF. The $\beta$ phase absorption appears at 504,840 and $1280 \mathrm{~cm}^{-}$ ${ }^{1}$. The absorption intensity of $\alpha$-phase decrease by increasing NZF contents whereas the intensity of $\beta$-phase absorption still unchanged by increasing NZF content. It was found that the broad absorption bands in the range of about 3180 to $3310 \mathrm{~cm}-1$ is attributed to the stretching of $\mathrm{O}-\mathrm{H}$ group of water bonded with PVDF molecule [18].

The DC electrical resistivity of both $\mathrm{Ni}_{0.3} \mathrm{Zn}_{0.7} \mathrm{Fe}_{2} \mathrm{O}_{4}$ and $\mathrm{x} \% \mathrm{Ni}_{0.3} \mathrm{Zn}_{0.7} \mathrm{Fe}_{2} \mathrm{O}_{4} / \mathrm{PVDF}$ samples is measured by the two probe method in the temperature range from room temperature up to $833 \mathrm{~K}$. The temperature dependence of DC electrical resistivity for both samples is shown in Figure $(7 \mathrm{a}, \mathrm{b})$. The transition from ferrimagnetic to paramagnetic states occurs at Curie temperature
$\mathrm{T}_{\mathrm{C}}$, and it is found to be $495 \mathrm{~K}$ for the first sample. The decrease of the DC resistivity with the increase in temperature is attributed to the thermal activation mobility of charge carriers. Figure $(5 \mathrm{~b})$ shows that the resistivity is nearly constant from $426 \mathrm{~K}$ to $558 \mathrm{~K}$ for all composite samples and the resistivity- temperature plot follow nonlinearity at high temperature.

Such features are generally observed for much amorphous polymeric system. The decrease of resistivity with temperature is interpreted as being due to a hopping mechanism which is a feature of the ferrite. The segmental motion of the polymer chain at higher temperature also causes the decrease of resistivity [19]. The nanoparticles of NZF can interact with PVDF chain. This interaction results in the structural modification of the polymer chain which affects the resistivity. There are two mechanisms of conduction in our composite samples, the ionic and hopping conduction. In pure PVDF and low ferrite content, the ionic conduction predominates. The ionic mechanism is affected by the presence of 5\% NZF which leads to increasing of the resistivity. Above this value the hopping conduction mechanism predominates leading to decrease of resistivity [20]. The continuous decrease of resistivity may be due to the increase of hopping length between ferric and ferrous ions octahedral site of ferrite. The change of conduction mechanism in the composite samples occurs at different temperatures depending on NZF content [21].

The activation energy EA for the thermally activated process was determined for the high temperature part of resistivity using the equation [22]:

$$
\rho=\rho_{\mathrm{o}} \exp \left(\frac{E_{A}}{K_{B} T}\right)
$$

and given in Table (2). In this temperature region the activation energy for all composite samples are positive and have a maximum at $10 \%$ NZF content [23]. The hopping conduction mechanism region in the resistivity decreases which indicates that the dipole orientation of the PVDF chain getting better. This means increasing of $\beta$ phase fraction. These results indicated that the piezoelectric properties of the composite film are improved [24]. The variation of dielectric constant $(\dot{\varepsilon})$ and dielectric loss $(\tan \delta)$ with temperature at a constant frequency of $1 \mathrm{kHz}$ for both samples, is shown in Figure $(8 \mathrm{a}, \mathrm{b})$ and Figure $(9 \mathrm{a}, \mathrm{b})$. Figure 
(9 a) show that the dielectric loss is found to increase with increasing temperature and have the same behavior of the dielectric constant. For NZF samples the dielectric constant gradually increases with temperature up to the Curie temperature and then increase sharply above $\mathrm{T}_{\mathrm{C}}$. The dielectric relaxation process can be identified by the electron hopping between $\mathrm{Fe}^{2+}$ and $\mathrm{Fe}^{3+}$ and occurs when the hopping frequency of the delocalized electric charge carriers become nearly equal to the frequency of external applied ac electric field. This relaxation appears for the sample $\mathrm{Ni}_{0.3} \mathrm{Zn}_{0.7} \mathrm{Fe}_{2} \mathrm{O}_{4}$. Figures $(8 \mathrm{~b}$ and $9 \mathrm{~b})$ reveal that both dielectric constant $(\dot{\varepsilon})$ and dielectric loss $(\tan \delta)$ for composite samples NZF/PVDF show a similar behavior as pure PVDF. The dielectric constant increases by increasing temperature and have a peak around the glass transition temperature $\left(\mathrm{T}_{\mathrm{g}}\right)$. This peak shifts to higher temperature about $253 \mathrm{~K}$ for the sample $15 \%$ NZF content and $273 \mathrm{~K}$ for other samples [25]. As shown in Figs. ( $8 \mathrm{~b}$ and $9 \mathrm{~b}$ ), the dielectric constant and dielectric loss are nearly independent of temperature up to $233 \mathrm{~K}$ and then increase gradually around $\mathrm{T}_{\mathrm{g}}$ and then sharply increase at higher temperature. The figures also show the dielectric constant and dielectric loss decrease by increasing the frequency of the applied field. The increase of dielectric constant can be ascribed to the increase of interfacial space charge polarization between PVDF and NZF nanoparticle and the increase of ionic mobility of the polymer due to interfacial interaction with the nanoparticles [26]. The dielectric properties may be altered by the onset of the magnetic transition or by the application of the magnetic field and vice versa. The PVDF/NZF composite exhibits large dielectric constant compared with that of pure PVDF. The dielectric constant is three times larger than pure PVDF. The dielectric loss for the composite samples is arranged from $0.02-0.05$ at $200 \mathrm{~K}$. The low value of $(\tan \delta)$ is suitable for energy storage application. As the temperature increases the hopping frequency increases leading to the increase of the relaxation time and thus the increase of $\tan \delta$. At low frequencies, as in our case $(1 \mathrm{KHz})$, a rise in the dielectric constant occurs at high temperature due to the increase of space charge resulting from the increase of charge carrier concentration in paramagnetic region.

The initial permeability $\mu_{\mathrm{i}}$ of pure $\mathrm{Ni}_{0.3} \mathrm{Zn}_{0.7} \mathrm{Fe}_{2} \mathrm{O}_{4}$ and $\mathrm{x} \% \mathrm{Ni}_{0.3} \mathrm{Zn}_{0.7} \mathrm{Fe}_{2} \mathrm{O}_{4}$ nano composite shown in Figure $(10 \mathrm{a}, \mathrm{b})$ respectively. As shown in Figure
(10 a) the initial permeability $\mu_{\mathrm{i}}$ increases by increasing temperature and has a maximum at about $620 \mathrm{~K}$, indicating the presence of single phase nanoferrite. After the maximum value, it decreases sharply and reaches the minimum value due to the transition from ferrimagnetic to paramagnetic state. As shown in Figure $(10 \mathrm{~b})$ the permeability decreases sharply at temperature near the glass transition temperature $\left(\mathrm{T}_{\mathrm{g}}\right)$ and reach its minimum value at the blocking temperature $\left(\mathrm{T}_{\mathrm{b}}\right)$. The magnetic permeability of the composite samples increase by increasing NZF content as shown in Table (2). The glass transition temperature $\left(\mathrm{T}_{\mathrm{g}}\right)$ increases with increasing NZF content indicating the increase of thermal stability of composite. So, there is the significant enhancement of thermal stability of the composite samples. The blocking temperature increases by increasing the ferrite content. According to this model and from relation [27-31]:

$$
\mu_{\mathrm{i}}=\frac{\mathbf{M}_{\mathrm{s}}{ }^{2} \mathbf{t}_{\mathrm{avg}}}{\mathbf{K}_{\mathrm{eff}}}
$$

by knowing $\mu_{\mathrm{i}}, \mathrm{M}_{\mathrm{s}}$ and $\mathrm{t}_{\mathrm{avg}}$ the magnetic crystalline anisotropy constant $\mathrm{K}_{\text {eff }}$ was calculated and given in Table (3). The value of the magnetic crystalline anisotropy constant $\mathrm{K}_{\mathrm{eff}}$ was in agreement with the value given in [9] for $\mathrm{NiFe}_{2} \mathrm{O}_{4} / \mathrm{PVDF}$ composite. The grain size can be also estimated from the lower concentrated composite with good dispersion of nanoparticle by using the measured values of the blocking temperature $\left(\mathrm{T}_{\mathrm{b}}\right)$ and the calculated values of the magnetic anisotropy using the relation [17]:

$$
\mathrm{T}_{\mathrm{b}}=\frac{\mathrm{K}_{\mathrm{eff}} \cdot \mathrm{V}}{25 \mathrm{~K}_{\mathrm{b}}}
$$

\section{Conclusion}

The sample $\mathrm{Ni}_{0.3} \mathrm{Zn}_{0.7} \mathrm{Fe}_{2} \mathrm{O}_{4}$ and its nanocomposite with PVDF $\mathrm{x} \% \mathrm{Ni}_{0.3} \mathrm{Zn}_{0.7} \mathrm{Fe}_{2} \mathrm{O}_{4}$ were prepared using high-energy ball milling. The crystallite sizes of the composite samples were estimated by broadening analysis of XRD peaks using Scherer's equation and were found $34-44 \mathrm{~nm}$. This is in coincidence with those measured from TEM micrograph. The $\alpha$-phase band at $745 \mathrm{~cm}^{-1}$ almost disappeared at $15 \% \mathrm{Ni}_{0.3} \mathrm{Zn}_{0.7} \mathrm{Fe}_{2} \mathrm{O}_{4}$ ferrite while the $\beta$-phase band increases at $839 \mathrm{~cm}^{-1}$. The scanning electron micrograph shows that the grain size tends to decrease by increasing the milling time, but increases with the high calcination temperature. The DC electrical resistivity for both 
samples has three regions with two breaks. The dielectric constant of the sample $\mathrm{Ni}_{0.3} \mathrm{Zn}_{0.7} \mathrm{Fe}_{2} \mathrm{O}_{4}$ at $1 \mathrm{KHz}$ slowly increases with the increase in the temperature. The initial permeability $\mu_{\mathrm{i}}$ increases by increasing temperature and has a maximum value at about $620 \mathrm{~K}$ indicating the presence of single phase nanoferrite.

Table (1): The calculated crystallite sizes

\begin{tabular}{ccc}
\hline $\mathrm{x} \%$ & $\mathrm{~T}(\mathrm{~nm})$ from XRD & $\mathrm{T}(\mathrm{nm})$ from TEM \\
\hline $\mathrm{PVDF}$ & & 52.4 \\
$5 \% \mathrm{Ni}_{0.3} \mathrm{Zn}_{0.7} \mathrm{Fe}_{2} \mathrm{O}_{4}$ & 44.23 & 49.33 \\
$10 \% \mathrm{Ni}_{0.3} \mathrm{Zn}_{0.7} \mathrm{Fe}_{2} \mathrm{O}_{4}$ & 32.516 & 57.5 \\
$15 \% \mathrm{Ni}_{0.3} \mathrm{Zn}_{0.7} \mathrm{Fe}_{2} \mathrm{O}_{4}$ & 35.278 & 46.5 \\
$20 \% \mathrm{Ni}_{0.3} \mathrm{Zn}_{0.7} \mathrm{Fe}_{2} \mathrm{O}_{4}$ & 36.034 & 45.8 \\
$25 \% \mathrm{Ni}_{0.3} \mathrm{Zn}_{0.7} \mathrm{Fe}_{2} \mathrm{O}_{4}$ & 34.253 & 49.33 \\
$100 \% \mathrm{Ni}_{0.3} \mathrm{Zn}_{0.7} \mathrm{Fe}_{2} \mathrm{O}_{4}$ & 37.793 & 48 \\
\hline
\end{tabular}

Table (2): The activation energy for the high temperature part of resistivity

\begin{tabular}{ccc}
\hline $\mathrm{x} \%$ & $\mathrm{E}_{\mathrm{A}}\left(\mathrm{E}_{\mathrm{v}}\right)$ & $\rho 300 \mathrm{k}(\Omega . \mathrm{m})$ \\
\hline $\mathrm{PVDF}$ & 0.085 & $5.55^{*} 10^{11}$ \\
$5 \% \mathrm{Ni}_{0.3}$ & 0.48 & $1.1^{*} 10^{12}$ \\
$10 \% \mathrm{Ni}_{0.3}$ & 0.87 & $3.57 * 10^{11}$ \\
$15 \% \mathrm{Ni}_{0.3}$ & 0.3 & $2.8 * 10^{11}$ \\
$20 \% \mathrm{Ni}_{0.3}$ & 0.35 & $4.4 * 10^{11}$ \\
$25 \% \mathrm{Ni}_{0.3}$ & 0.22 & $1.17 * 10^{11}$ \\
\hline
\end{tabular}

Table (3): $\mu_{\mathrm{i}}(\mathrm{H} / \mathrm{m}), \mathbf{T}_{\mathrm{b}}(\mathrm{K}), \mathrm{K}_{\text {eff }}\left(\mathrm{erg} / \mathrm{cm}^{3}\right)$ and $\mathbf{T}_{\mathrm{g}}(\mathrm{K})$

\begin{tabular}{ccccc}
\hline $\mathrm{x} \%$ content & $\mu_{\mathrm{i}}(\mathrm{H} / \mathrm{m})$ & $\mathrm{T}_{\mathrm{b}}(\mathrm{K})$ & $\mathrm{K}_{\text {eff }}\left(\mathrm{erg} / \mathrm{cm}^{3}\right)$ & $\mathrm{T}_{\mathrm{g}}(\mathrm{K})$ \\
\hline $\mathrm{PVDF}$ & 2044.1 & 375 & - & 238 \\
$5 \% \mathrm{Ni}_{0.3}$ & 2641.3 & 291 & $0.82 * 10^{4}$ & 220 \\
$10 \% \mathrm{Ni}_{0.3}$ & 2892.3 & 307 & $1.86 * 10^{4}$ & 231 \\
$15 \% \mathrm{Ni}_{0.3}$ & 2223 & 305 & $3.5 * 10^{4}$ & 244 \\
$20 \% \mathrm{Ni}_{0.3}$ & 2949.5 & 310 & $2.78^{*} 10^{4}$ & 240 \\
$25 \% \mathrm{Ni}_{0.3}$ & 5080.8 & 375 & $11.43^{*} 10^{4}$ & 252 \\
$100 \% \mathrm{Ni}_{0.3}$ & $9.35 * 10^{5}$ & - & $1.25 * 10^{4}$ & - \\
\hline
\end{tabular}




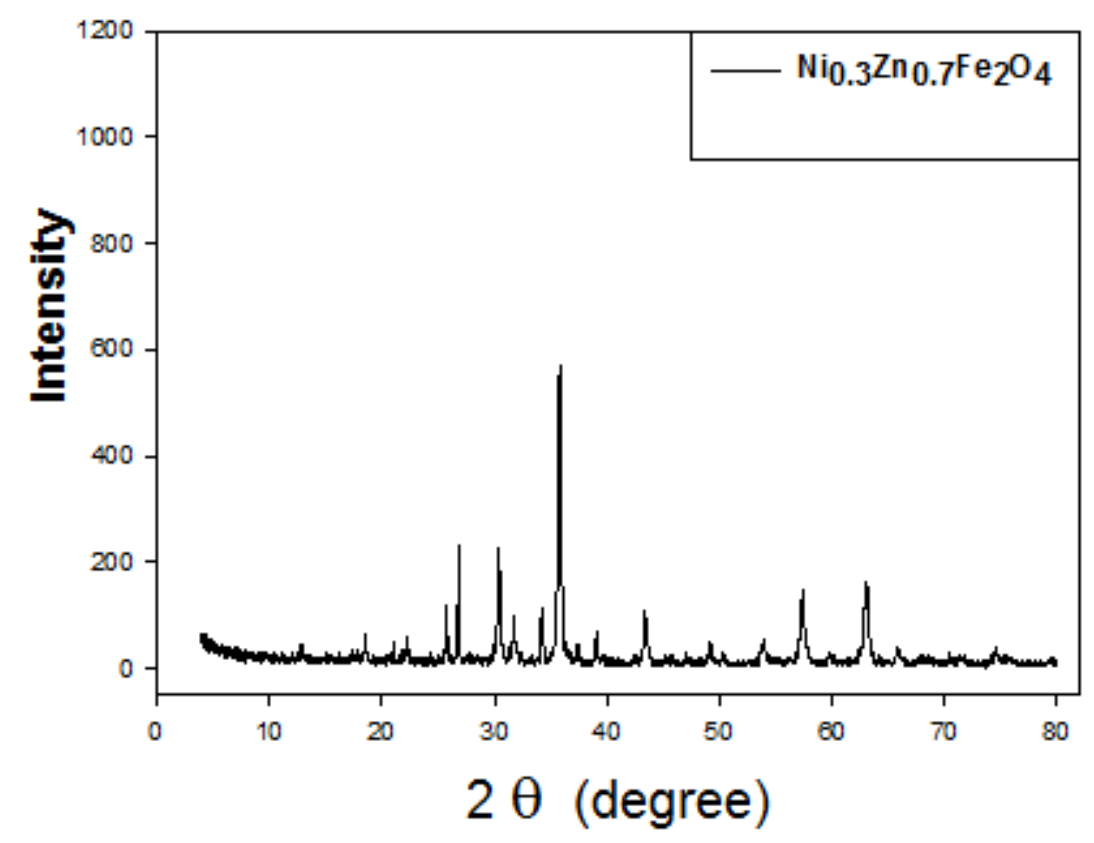

(a)

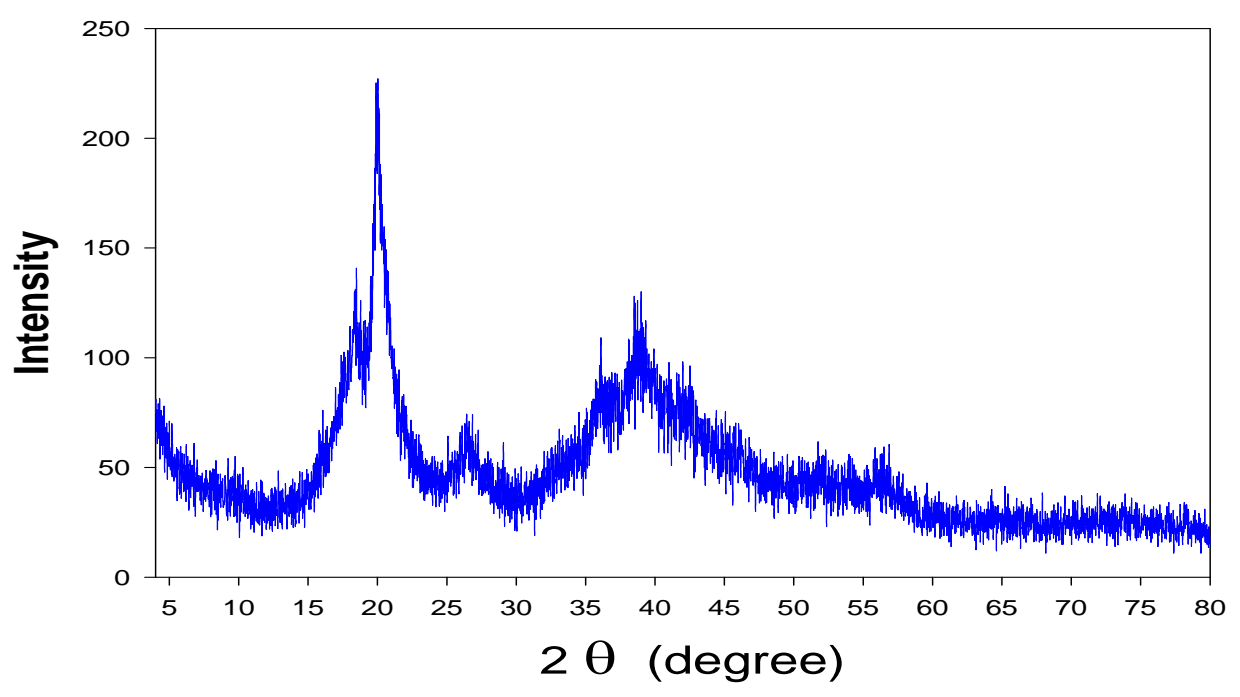

(b)

Figure (1): The XRD for (a) pure $\mathrm{Ni}_{0.3} \mathrm{Zn}_{0.7} \mathrm{Fe}_{2} \mathrm{O}_{4}$ and (b) pure PVDF 


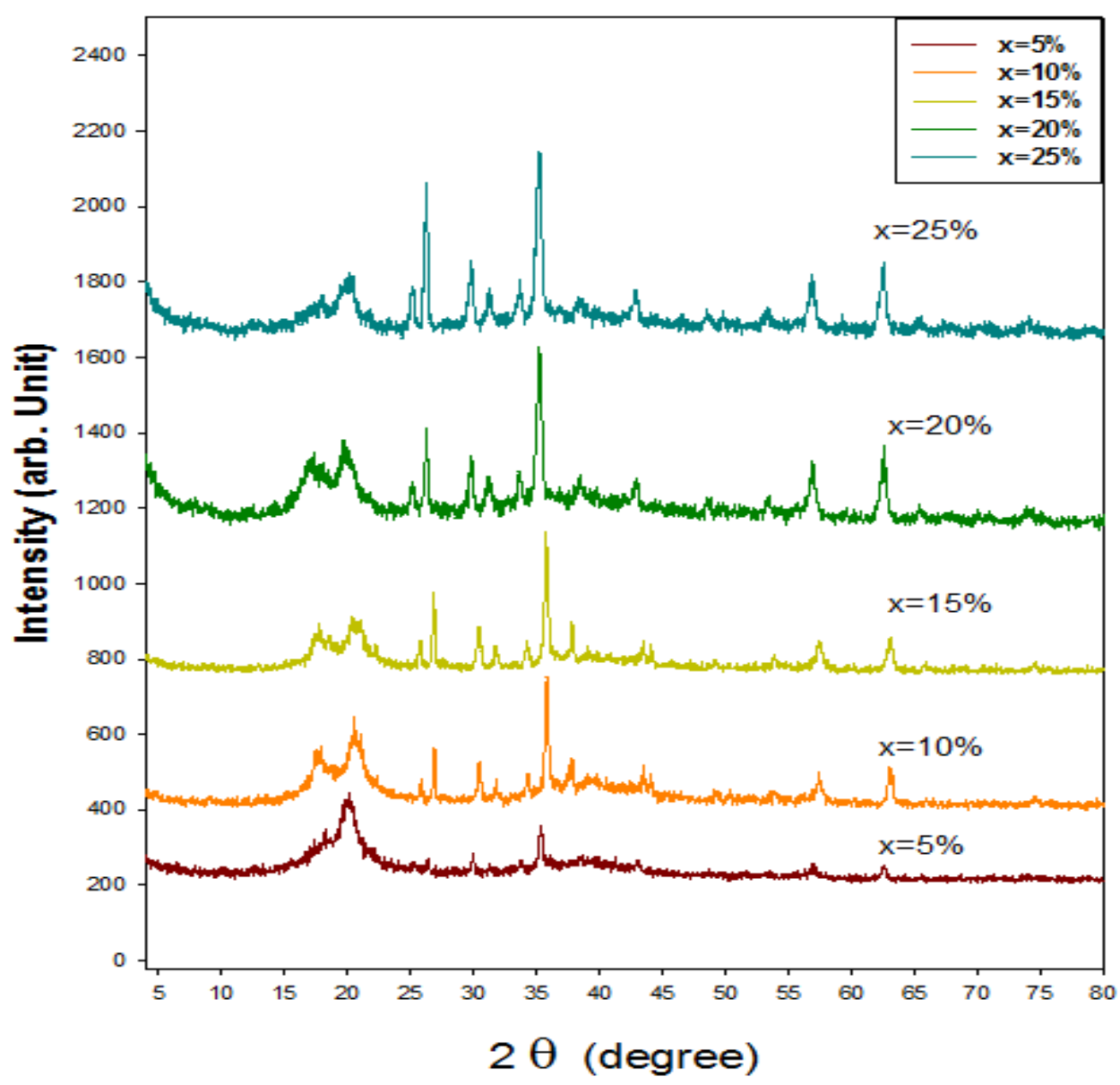

Figure (2): The XRD for $x \% \mathrm{Ni}_{0.3} \mathrm{Zn}_{0.7} \mathrm{Fe}_{2} \mathrm{O}_{4} / \mathrm{PVDF}$ nanocomposites

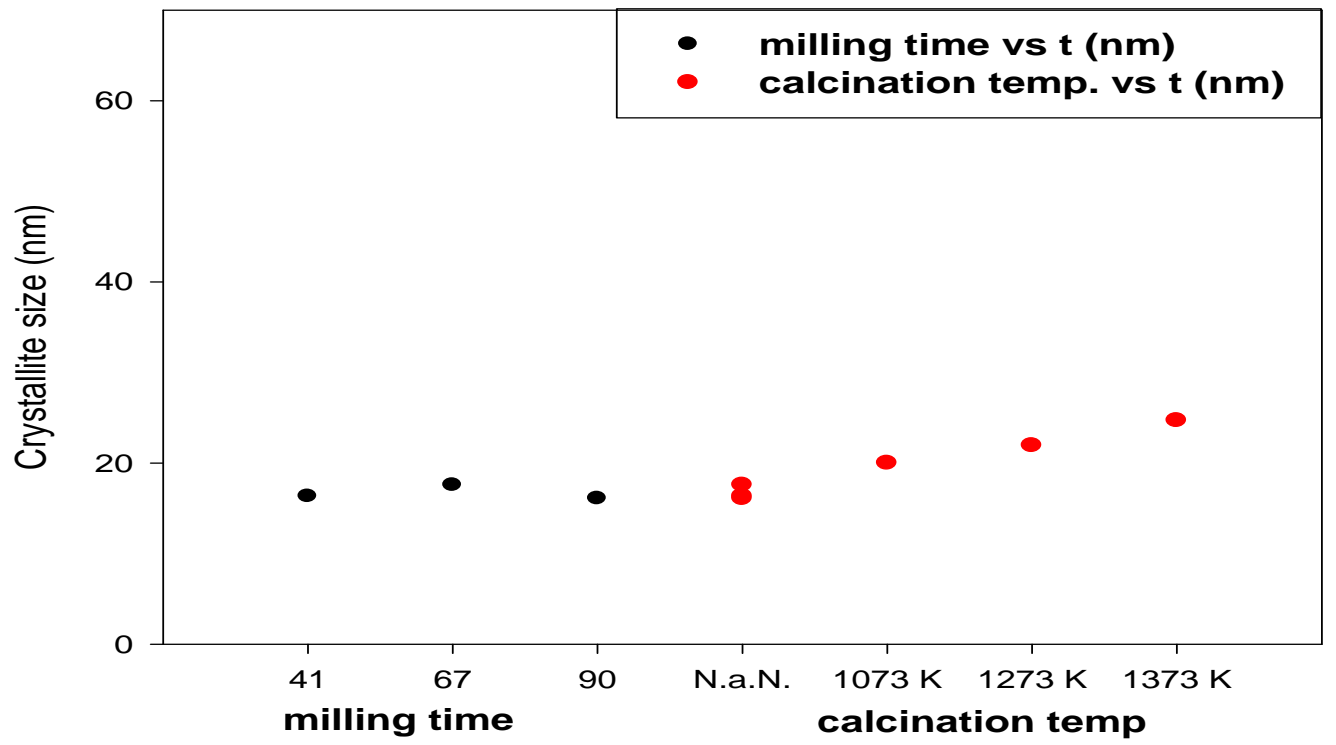

Figure (3): Crystallite size as function of calcination temperature and milling time for the samples $\mathrm{Ni}_{0.3} \mathrm{Zn}_{0.7} \mathrm{Fe}_{2} \mathrm{O}_{4}$ 


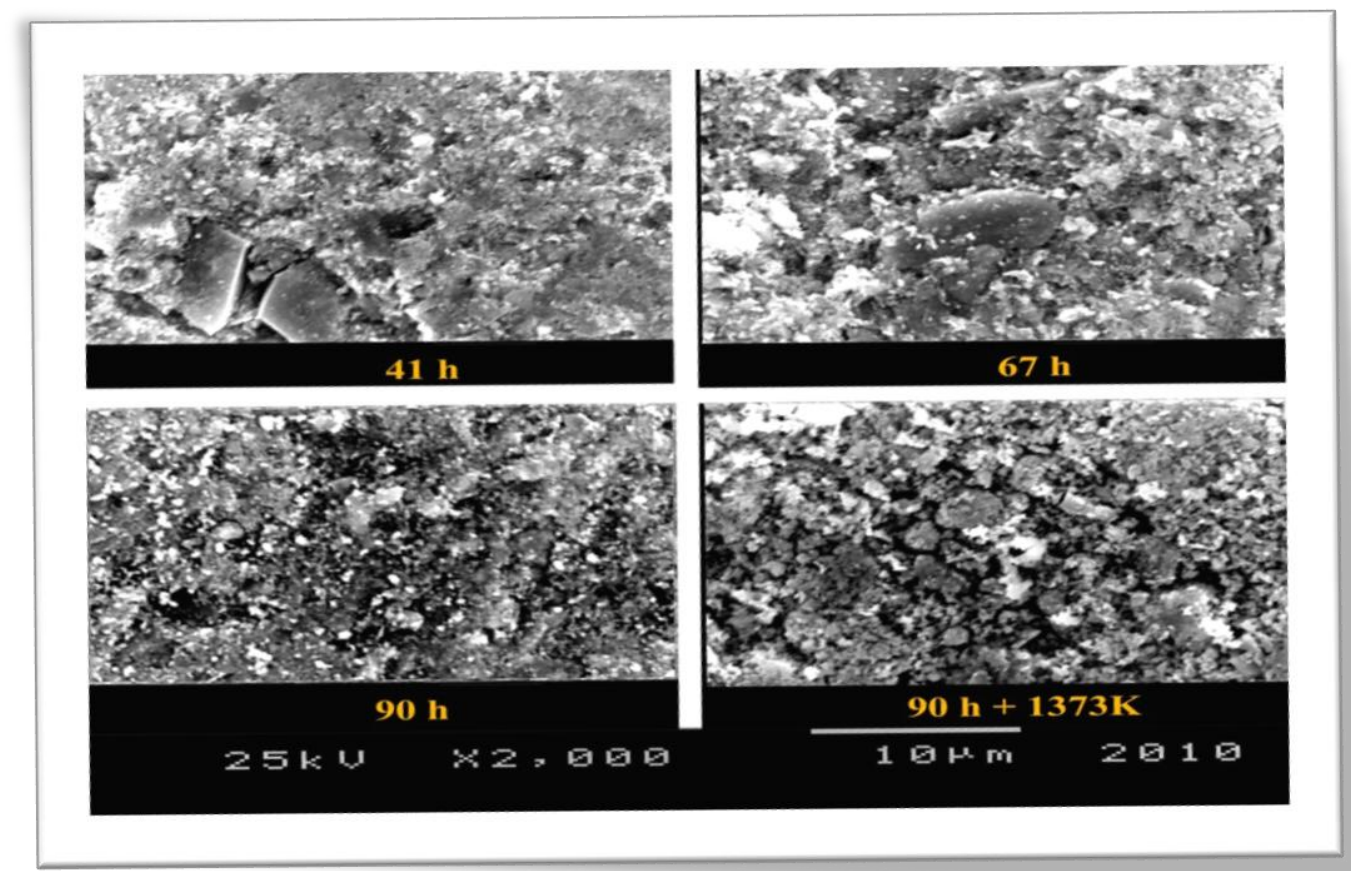

Figure (4): SEM for the sample $\mathrm{Ni}_{0.3} \mathrm{Zn}_{0.7} \mathrm{Fe}_{2} \mathrm{O}_{4}$
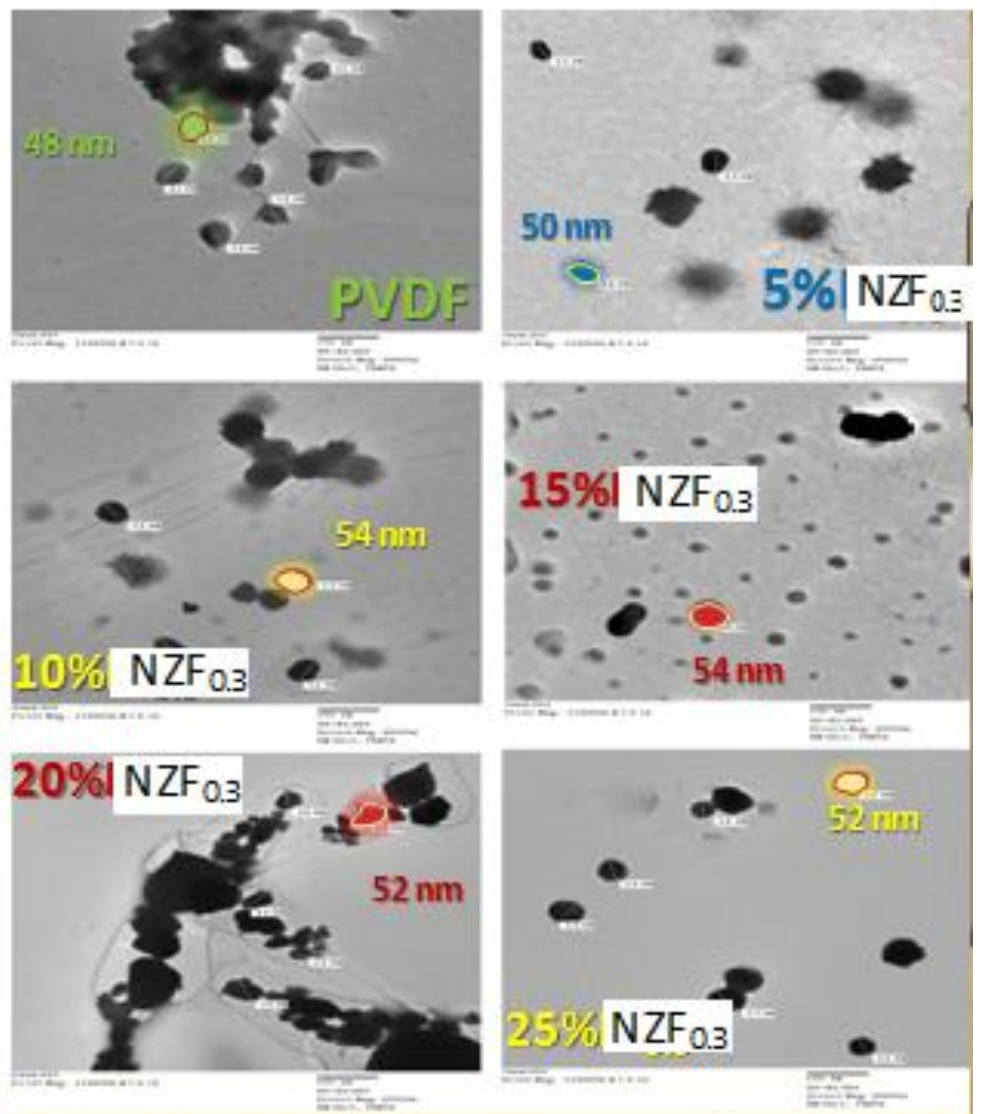

Figure (5): The TEM micrograph of pure PVDF and $x \% \mathrm{Ni}_{0.3} \mathrm{Zn}_{0.7} \mathrm{Fe}_{2} \mathrm{O}_{4} / \mathrm{PVDF}$ 


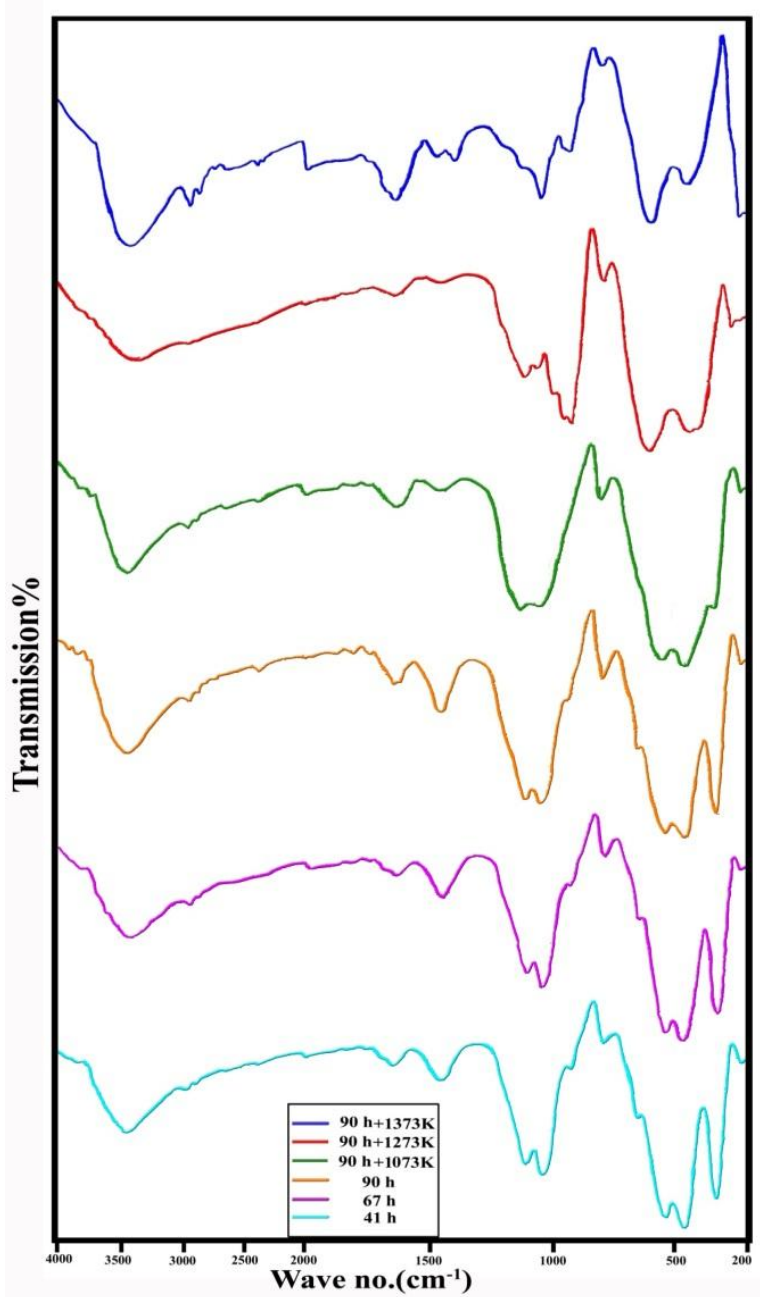

(a)

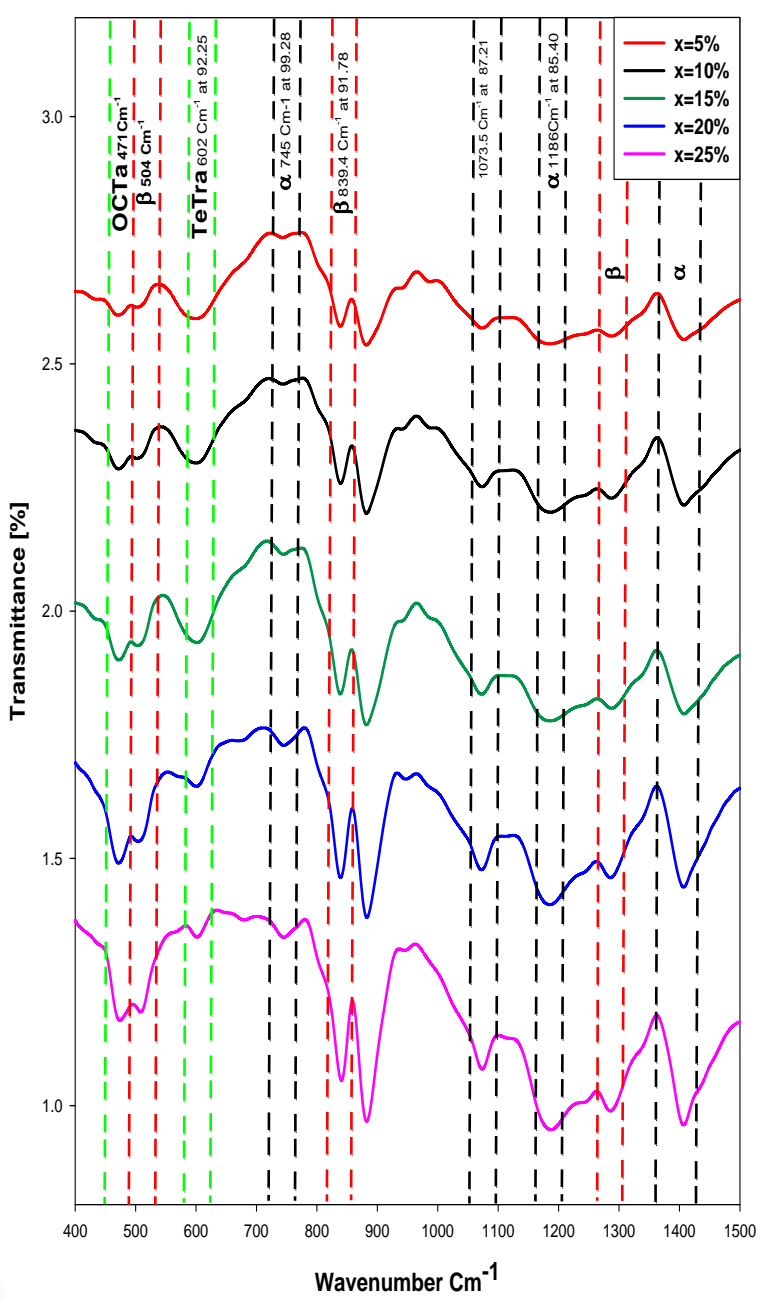

(b)

Figure (6): IR for (a) $\mathrm{Ni}_{0.3} \mathrm{Zn}_{0.7} \mathrm{Fe}_{2} \mathrm{O}_{4}$ and (b) $\mathrm{x} \% \mathrm{Ni}_{0.3} \mathrm{Zn}_{0.7} \mathrm{Fe}_{2} \mathrm{O}_{4} / \mathrm{PVDF}$ nanocomposites

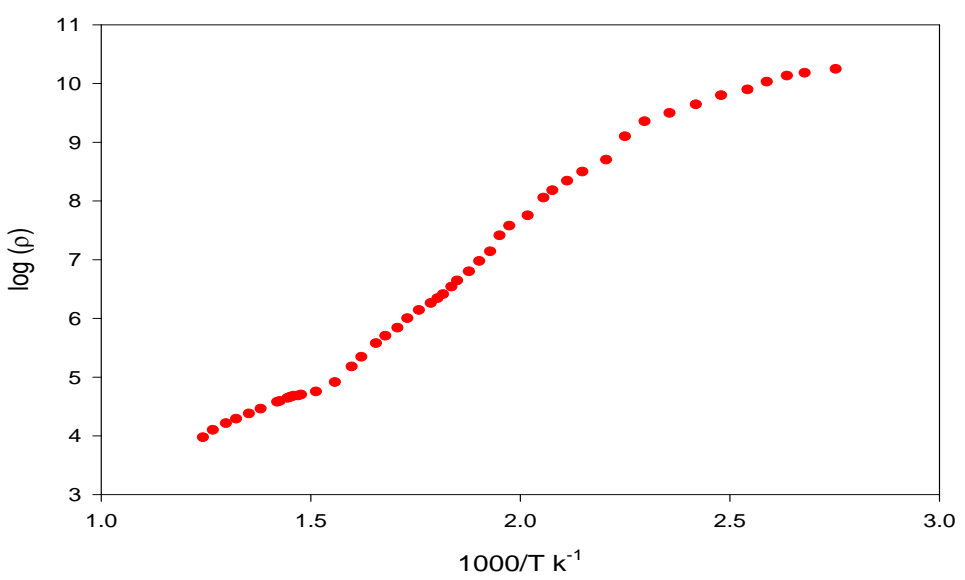

(a) 

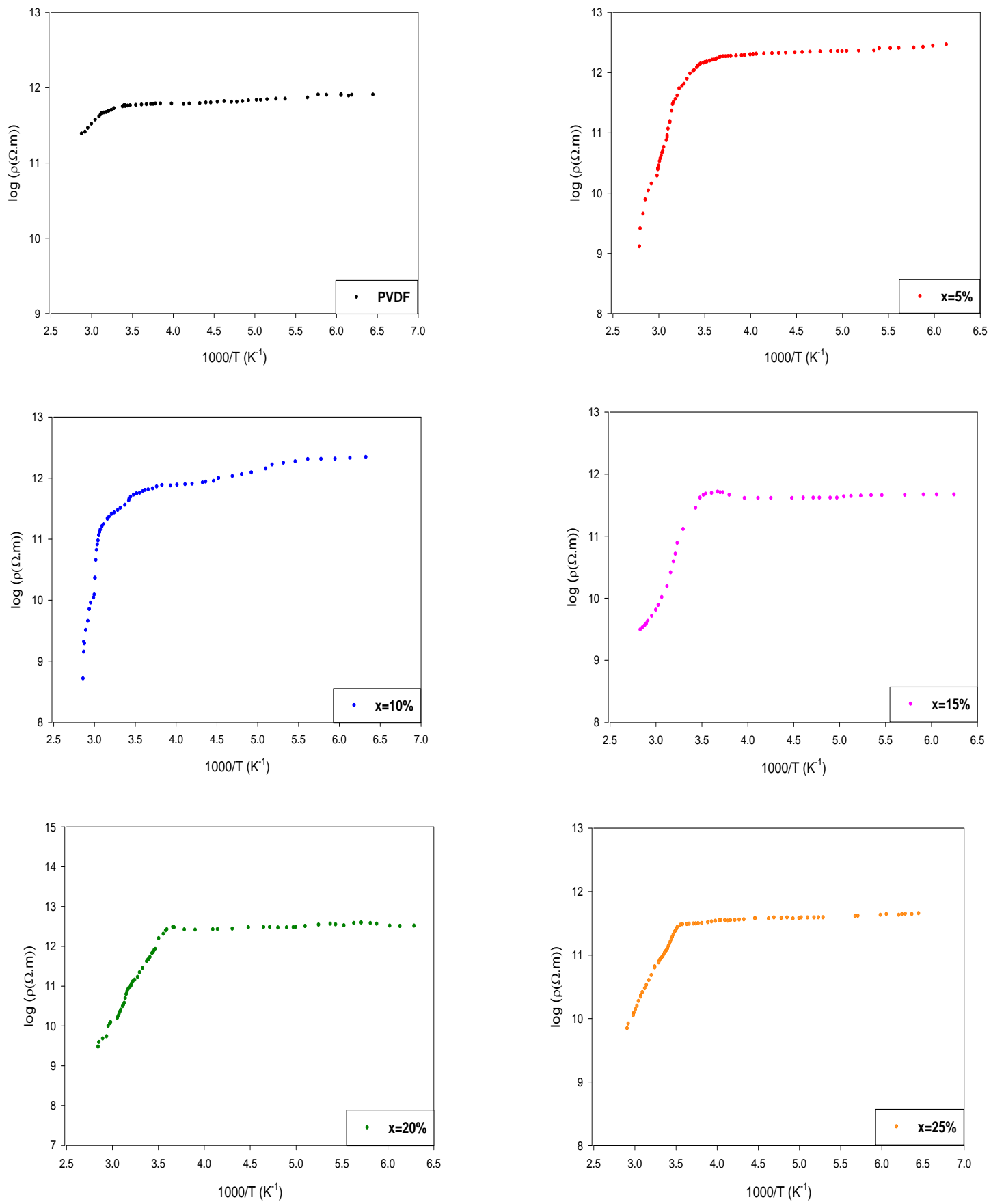

(b)

Figure (7): The DC resistivity for (a) $\mathrm{Ni}_{0.3} \mathrm{Zn}_{0.7} \mathrm{Fe}_{2} \mathrm{O}_{4}$ and (b) $\mathrm{x} \% \mathrm{Ni}_{0.3} \mathrm{Zn}_{0.7} \mathrm{Fe}_{2} \mathrm{O}_{4} / \mathrm{PVDF}$ nanocomposites 


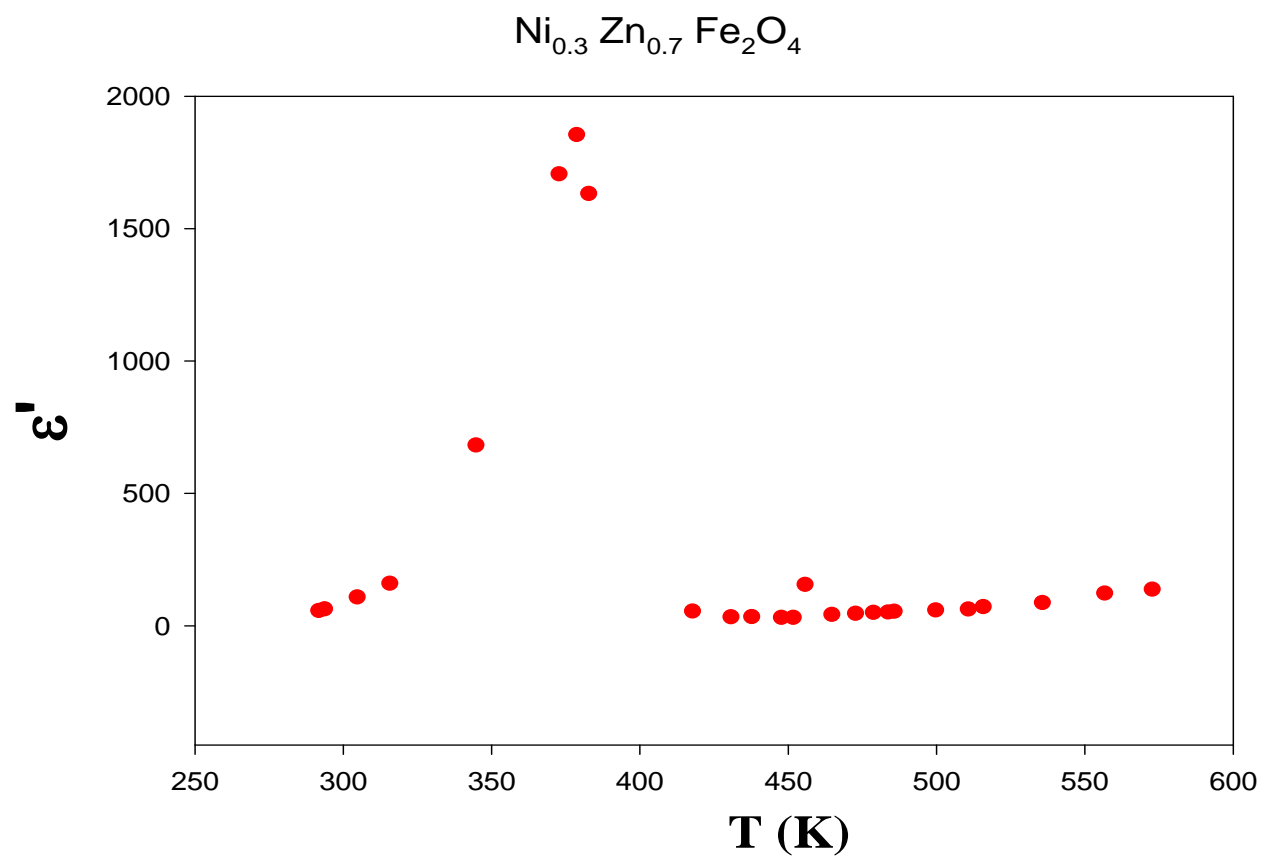

(a)
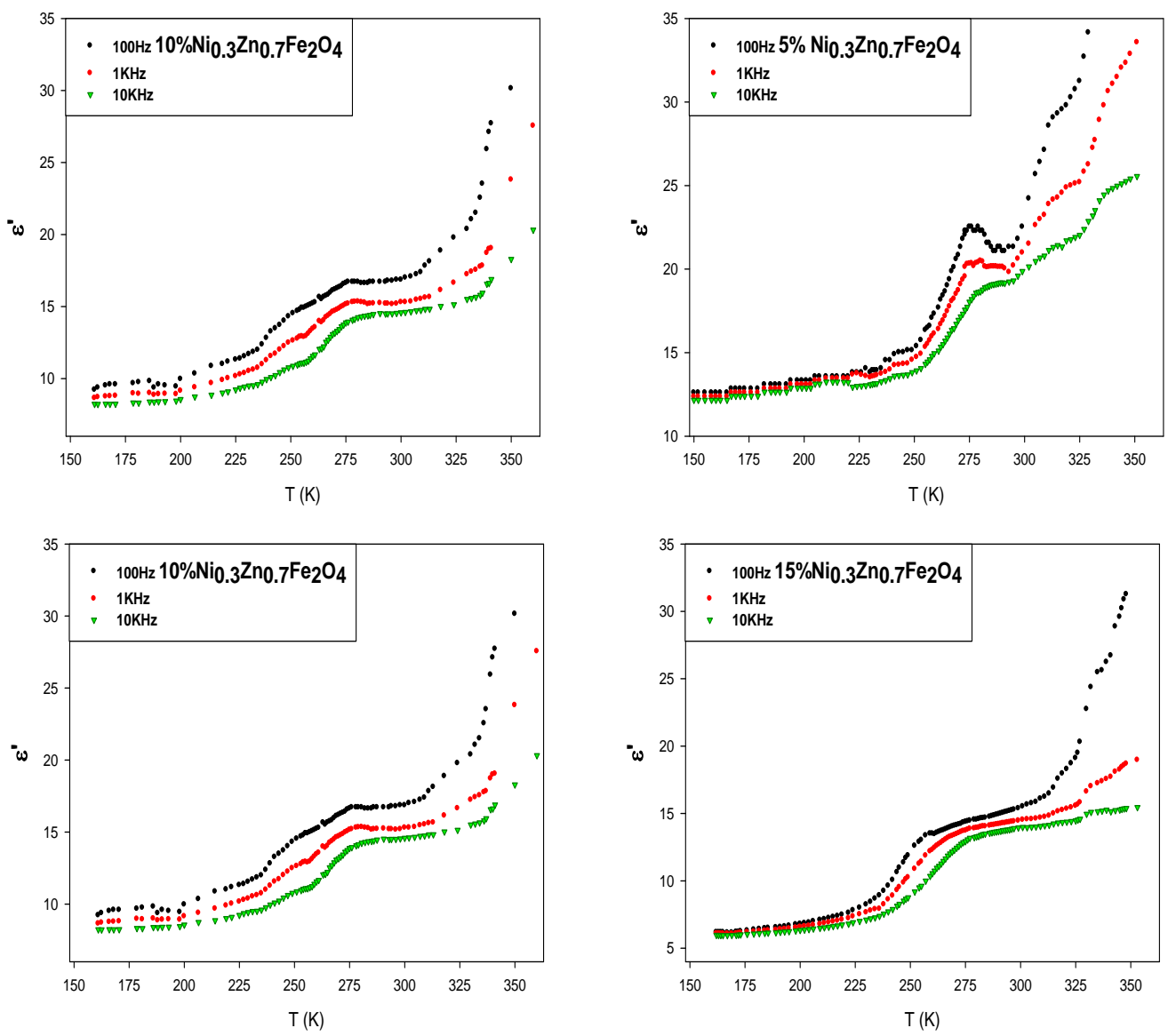

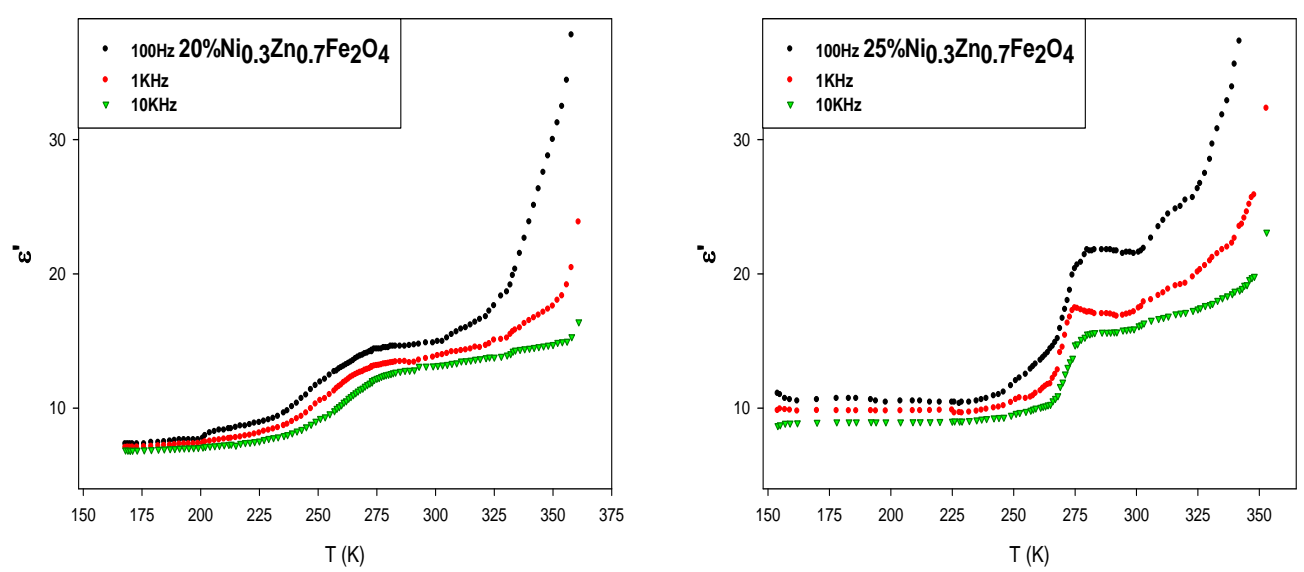

(b)

Figure (8 a, b): The dielectric constant for (a) $\mathrm{Ni}_{0.3} \mathrm{Zn}_{0.7} \mathrm{Fe}_{2} \mathrm{O}_{4}$ and (b) pure PVDF and $\mathrm{x} \% \mathrm{Ni}_{0.3} \mathrm{Zn}_{0.7} \mathrm{Fe}_{2} \mathrm{O}_{4} / \mathrm{PVD}$

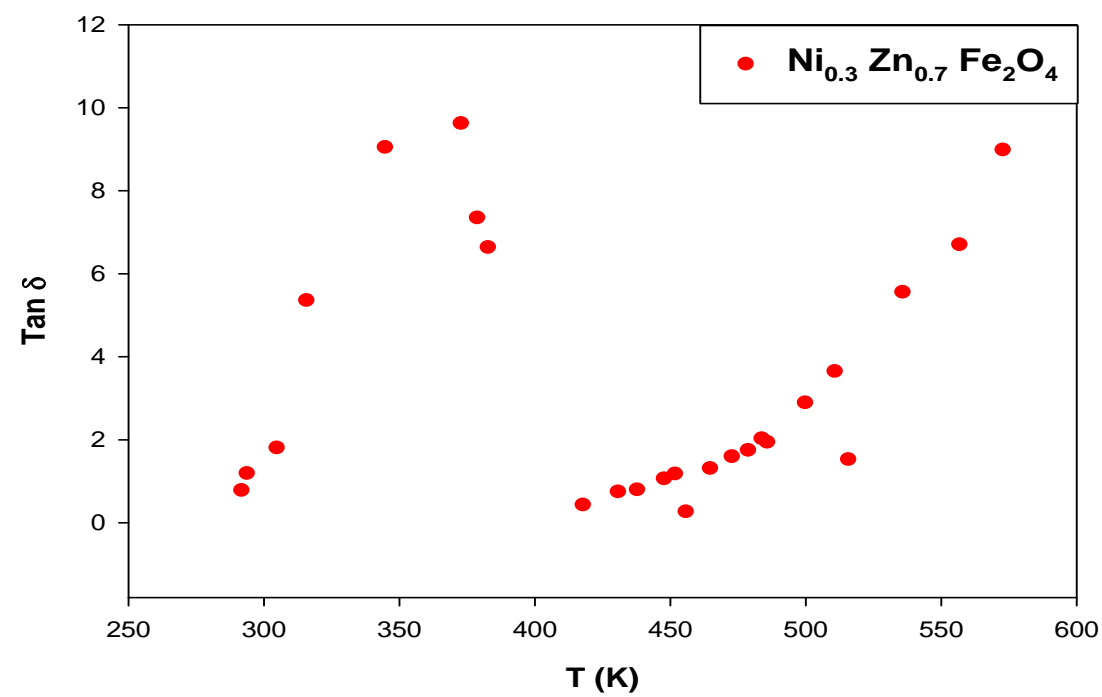

(a) 

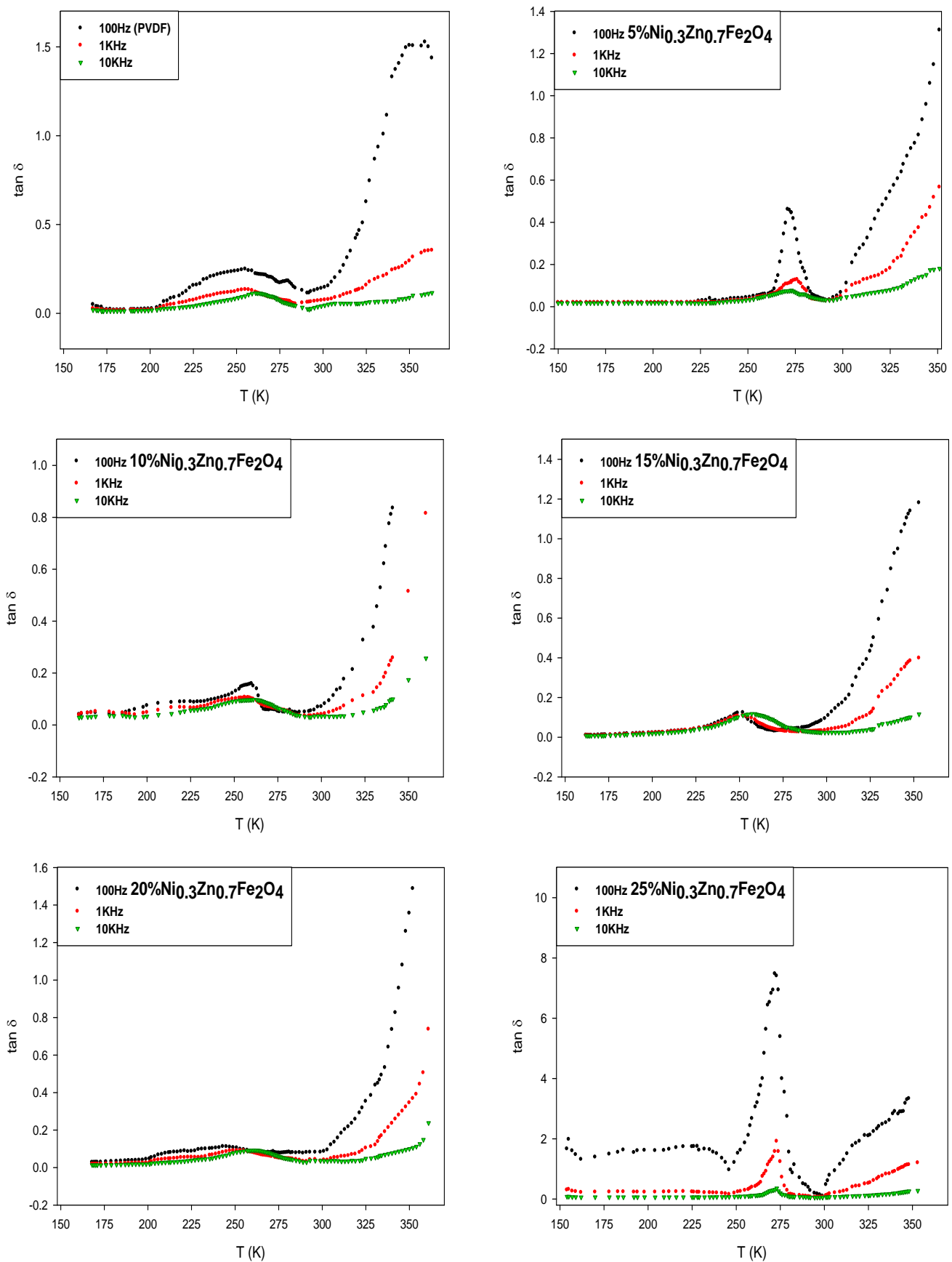

(b)

Figure (9 a, b): The dielectric loss for (a) $\mathrm{Ni}_{0.3} \mathrm{Zn}_{0.7} \mathrm{Fe}_{2} \mathrm{O}_{4}$ and (b) pure $\mathrm{PVDF}$ and $\mathrm{x} \% \mathrm{Ni}_{0.3} \mathrm{Zn}_{0.7} \mathrm{Fe}_{2} \mathrm{O}_{4} / \mathrm{PVD}$ 

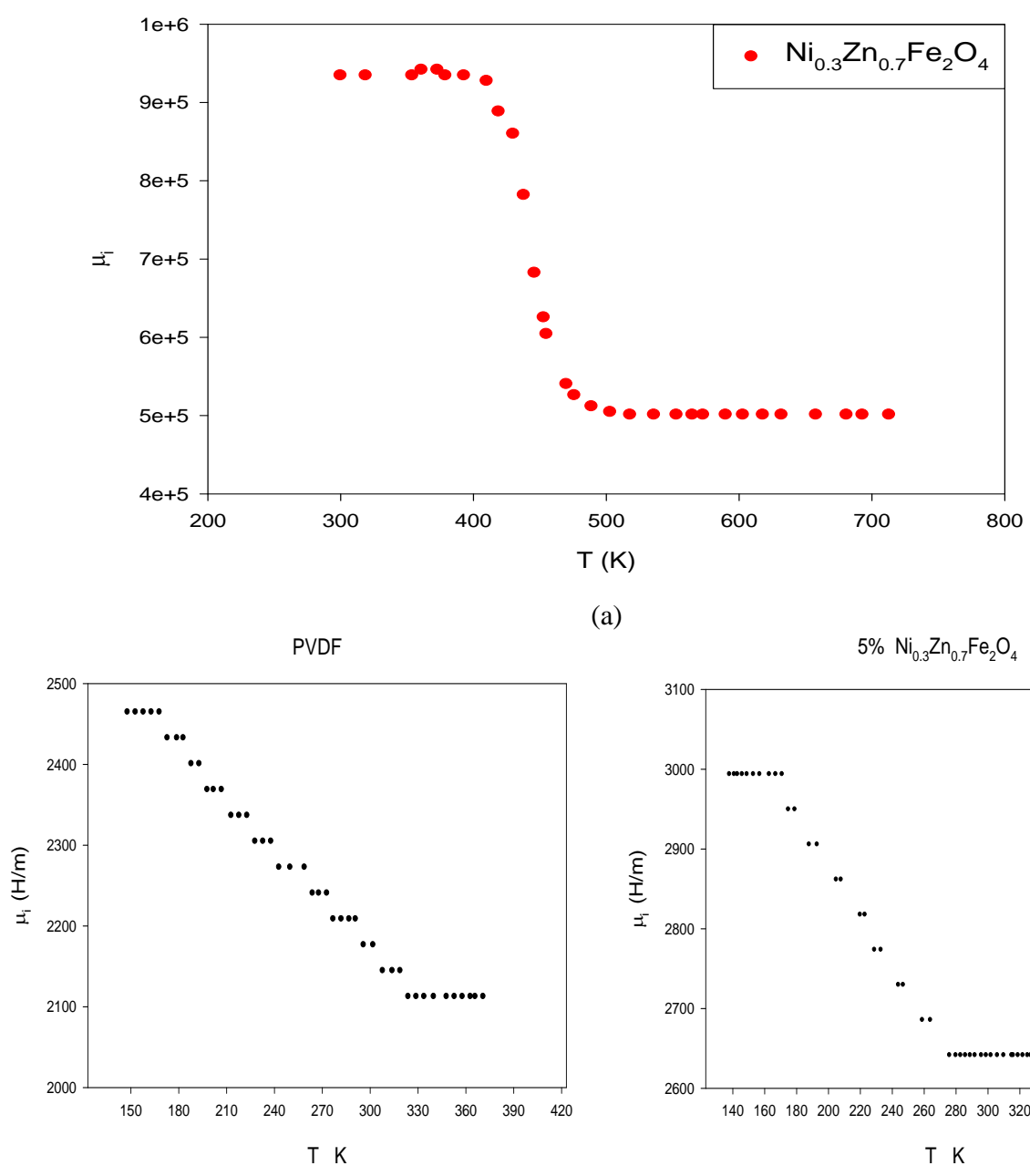

(a)
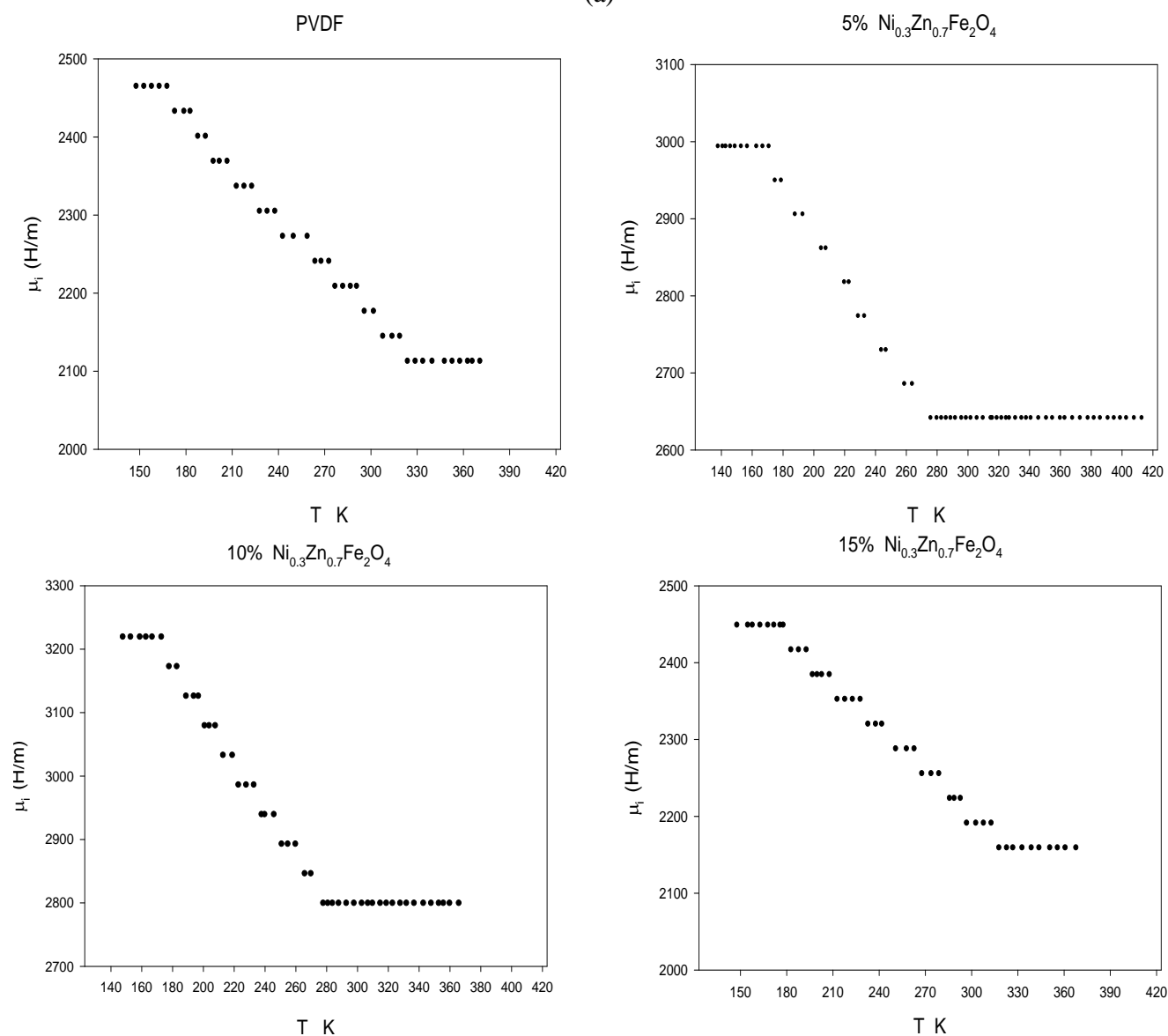

$15 \% \mathrm{Ni}_{0.3} \mathrm{Zn}_{0.7} \mathrm{Fe}_{2} \mathrm{O}_{4}$

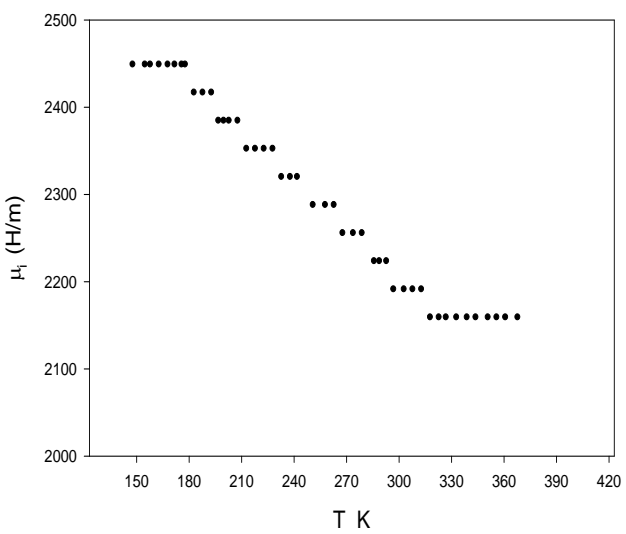



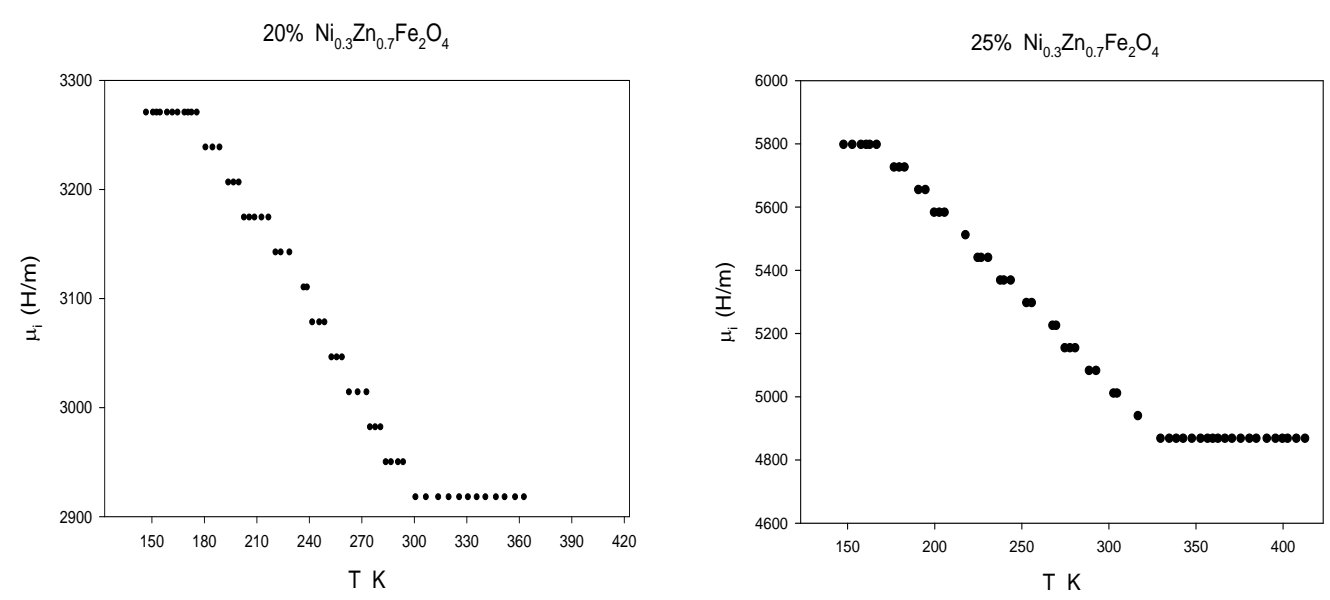

(b)

Figure (10 a, b): Magnetic permeability for (a) $\mathrm{Ni}_{0.3} \mathrm{Zn}_{0.7} \mathrm{Fe}_{2} \mathrm{O}_{4}$ and (b) $\mathrm{x} \% \mathrm{Ni}_{0.3} \mathrm{Zn}_{0.7} \mathrm{Fe}_{2} \mathrm{O}_{4} / \mathrm{PVD}$

\section{References}

1- K. Krieble, T. Schaeffer, J. Applied Physics 97, 10F101 (2005).

2- L. Zhao, Y. Cui, H. Yang, L. Yu, W. Jin, S. Feng, Materials Letters 60, 104, (2006).

3- A. Thakur, P. Mathur, M. Singh, J. Physics and Chemistry of Solids 68, 378, (2007).

4- G. Kumar, J. Chand, S. Verma, M. Singh, J. Physics D: Applied Physics 42, 155001 (2009).

5-M. C. Dimri, A. Verma, S. C. Kashyap, D. C. Dube, O. P. Thakur, C. Prakash, Materials Science and Engineering B133, 42 (2006).

6-K. Gagan, C. Jagdish, V. Satish, M. Singh, J. Physics D: Applied Physics 42, (155001) 2009.

7-Y. Bar-Cohen, T. Xue and S. Lih, NDTnet, 1 (9), (1996).http://www.ndt.net/article/yosi/yosi.htm

8-R. Gregorio, and E. M. Ueno, Journal of Material Science, 34 (18), 4489- 4500 (1999).

9-H. Xu, G. Shanthi, V. Bharti, Q. M. Zhang, and T. Ramatowski, Macromolecules, 33 (11), 4125-4131 (2000).

10-T. Furukawa, Phase Transitions, 18 (3-4), 143211(1989).

11-[11] A. J. Lovinger, "Poly(vinylidene fluoride)", Developments in Crystalline Polymers, Applied Science Publishers Ltd, Englewood, NJ, (1982).

21-M. Y. Chung, and D. C. Lee, Journal of the Korean Physical Society, 38 (2), 117-122 (2001).

22-P. A. Shaikh, R. C. Kambale, A. V. Rao, and Y. D. Kolekar, J. Alloys Compd., 492 (1-2), 590-596 (2010).
12-X. Yang, X. Kong, S. Tan, G. Li, W. Ling, and E. Zhou, Polymer International, 49(11), 15251528(2000).

13-G. F. Goya, H. R. Rechenberg, and J. Z. Jiang, J. Appl. Phys., 84 (2), 1101 - 1108 (1998).

14-B. P. Rao, O. Caltun, I. Dumitru, and L. Spinu, J. Magn. Magn. Mater., 304 (2), e752-e754 (2006).

15-B. Bajaj, B. D. Malhotra, and S. Choi, Thin Solid Films, 519 (3), 1219-(2010).

16-B. Cullity, "Elements of Xiray Diffraction", Addison-Wesley, Reading, MA, (1959) 514.

17-P. Martins, C. M. Costa, G. Botelho, S. LancerosMendez, J. M. Barandiaran, and J. Gutierrez, Materials Chemistry and Physics, 131 (3),698-705 (2012).

18-S. Chen, X. Li, K. Yao, F. E. H. Tay, A. Kumar, and K. Zeng, Polymer, 53(6), 1404-1408 (2012).

19-S. Rajendran, P. Sivakumar, and R. S. Babu, Bull. Mater. Sci., 29 (7), 673-678 (2006).

20-A. S. Bhatt, D. K. Bhat, and M. S. Santosh, Journal of Applied Polymer Science, 119 (2), 968-972 (2011).

23-M. Abdelaziz, J. Magn. Magn. Mater., 279 (2-3), 184-194 (2004).

24-A. Hartono, S. Satira, M. Djamal, Ramli, and E. Sanjaya, IOSR Journal of Applied Physics, 3 (1), 7 11 (2013). 
25-R. D. Simoes, M. A. Rodriguez-Perez, J. A. de Saja, and C. J. L. Constantino, Journal of Thermal Analysis and Calorimetry, 99 (2), 621 - 629 (2010).

26-X. Wang, W. Li, L. Luo, Z. Fang, J. Zhang, and Y. Zhu, J. Appl. Polym. Sci., 125 (4), 2711-2715 (2012).

27-D. N. Bhosale, N. D. Choudhari, S. R. Sawant, and P. P. Bakare, J. Magn. Magn. Mater., 173 (1-2), 51 58 (1997).
28-M. M. Haque, M. Huq, and M. A. Hakim, J. Magn. Magn. Mater., 320 (21), 2792- 2799 (2008).

29-A. Globus, P. Duplex, and M. Guyot, IEEE Trans. Magn., MAG-7 (3), 617-622 (1971).

30-S. S. Bellad, and B. K. Chougule., Materials Research Bulletin, 33 (8), 1165-1173 (1998).

31-S. A. Patil, B. V. Bhise, and A. K. Ghatage, Materials Chemistry and Physics, 65 (1), 38-45 (2000). 